\title{
1 Increase in Ozone due to the Use of Biodiesel Fuel Rather
}

5 1) Department of Applied Chemistry, Graduate School of Engineering, Osaka Prefecture

6 University, 1-1 Gakuen-cho, Naka-ku, Sakai-shi, Osaka 599-8531, Japan

7 2) Institute of Environmental Technology (IET), Vietnam Academy of Science and Technology

8 (VAST), 18 Hoang Quoc Viet Street, Nghia Do, Cau Giay, Hanoi, Vietnam

9 3) Research Organization for University-Community Collaborations, Osaka Prefecture

10 University, 1-2 Gakuen-cho, Naka-ku, Sakai, Osaka 599-8531, Japan

11 4) Osaka City Institute of Public Health \& Environmental Sciences, 8-34 Tojo-cho, Tennoji-ku,

12 Osaka 543-0026, Japan.

13 Key word: Ozone increment, Biodiesel Fuel, Emission, Vietnam, $\mathrm{NMHCs}, \mathrm{NO}_{\mathrm{x}}$

\section{$15 \quad$ Abstract}

16 The consumption of fuel by vehicles emits nitrogen oxides $\left(\mathrm{NO}_{\mathrm{x}}\right)$ and non-methane

17 hydrocarbons (NMHCs) into the atmosphere, which are important ozone precursors. Ozone is

18 formed as a secondary pollutant via photochemical processes and is not emitted directly into the 
19 atmosphere. In this paper, the ozone increase resulting from the use of biodiesel and diesel fuels

20 was investigated, and the different ozone formation trends were experimentally evaluated.

21 Known amounts of exhaust gas from a power generator operated using biodiesel and diesel fuels

22 were added to ambient air. The quality of the ambient air, such as the initial $\mathrm{NMHC}$ and $\mathrm{NO}_{\mathrm{x}}$

23 concentrations, and the irradiation intensity have an effect on the ozone levels. When $30 \mathrm{~cm}^{3}$ of

24 biodiesel fuel exhaust gas (BFEG) or diesel fuel exhausted gas (DFEG) was added to $18 \mathrm{dm}^{3}$ of

25 ambient air, the highest ratios of ozone increase from BFEG compared with DFEG in Japan and

26 Vietnam were 31.2 and $42.8 \%$, respectively, and the maximum ozone increases resulting from

27 DFEG and BFEG compared with the ambient air in Japan were 17.4 and $26.4 \mathrm{ppb}$, respectively.

28 The ozone increase resulting from the use of BFEG was large and significant compared to that

29 from DFEG under all experimental conditions. The ozone concentration increased as the amount

30 of added exhaust gas increased. The ozone increase from the Jatropha-BFEG was slightly higher

31 than that from waste cooking oil-BFEG.

32 Capsule "The first ozone increment in the use of biodiesel fuel was experimentally evaluated,

33 and compared the ozone increment between biodiesel and petroleum diesel fuel".

\section{$34 \quad$ Highlights}

$35+$ Ozone increment with the use of biodiesel fuel rather than diesel fuel

$36+$ Ozone increment was evaluated by direct experimental measurement

37 + The ozone concentration was increased with increasing amount of exhausted gas addition

$38+$ Due to different ambient air composition, the trend of ozone increment between Vietnam and

39 Japan are different

$40 \quad$ Introduction 
The ozone layer in the stratosphere plays an important protective role; however, tropospheric

42 ozone is a photochemical oxidant. Ozone is a secondary pollutant that is produced from volatile

43 organic compounds (VOCs) and $\mathrm{NO}_{\mathrm{x}}$ under sunlight (Orlando et al., 2010). It reacts with some

44 gases, such as $\mathrm{NO}, \mathrm{NO}_{2}$ and alkenes, as well as with some surfaces, leaves, and biological

45 membranes. These reactions can damage living cells and human lungs. Exposure to ozone has

46 been associated with several adverse health effects and decreased lung function (Hadavi, 2013).

47 Ozone pollution at the ground level is an environmental concern in the US, Brazil, China, Japan, 48 and other countries.

49 Understanding the increases in ozone production will help improve predictability and reduce 50 ozone pollution by controlling $\mathrm{NO}_{\mathrm{x}}$ and VOCs emissions. A considerable number of studies on

51 the ozone increases resulting from emissions from vehicles, engines and generators operating

52 using various fuels have been conducted; however, most of these studies were conducted using 53 modeling, computer simulations or direct tailpipe measurements (Mellouki et al., 2015; Shin et

54 al., 2016). To assess the ozone formation potential in the atmosphere and the importance of

55 NMHC precursors, the maximum incremental reactivity (MIR), also known as the maximum

56 ozone incremental reactivity (MOIR) was proposed by Carter in the late 1980s (Carter and

57 Atkinson, 1987, 1989). The values for quantifying the relative ground-level ozone impacts of

58 VOCs and associated uncertainty classifications have been updated (Carter, 1994; Carter, 2010;

59 Carter et al., 1995), and these values have been used to describe the maximum ability of a certain

60 hydrocarbon to produce ozone under specific atmospheric conditions.

61 The production, emissions, and benefits of biodiesel fuel (BDF) have been the focus of studies

62 for several decades. Currently, the benefits of using biodiesel fuel include its ability to mitigate

63 emissions that cause global warming; its ability to minimize $\mathrm{CO}, \mathrm{SO}_{2}$ and particulate emissions 
64 (Basha et al., 2009; Basha and Raja G., 2012; Guarieiro et al., 2009; Zhu et al., 2010); and its use

65 as an alternative to fossil fuels, which are continuously being depleted. Previous studies have

66 shown some negative aspects related to the use of biodiesel, such as increased emissions of low-

67 molecular-weight methyl esters (Thang et al., 2014, 2016) and carbonyl compounds (Chai et al.,

68 2013; Dong et al., 2014; Guarieiro et al., 2009; Schröder, 1999), increased ozone formation

69 potential (OFP) (Chai et al., 2013; Gentner et al., 2013; Li et al., 2011) and increased $\mathrm{NO}_{\mathrm{x}}$

70 concentration compared to conventional diesel fuel emission (Dorado et al., 2003; Fernando et

71 al., 2005; Guarieiro et al., 2009; Lin et al., 2006; Ribeiro et al., 2016; Xue et al., 2011). The

72 majority of published reports examine biodiesel production, engine performance and biodiesel

73 emissions. Biodiesel emissions have also been considered when BDFs were used rather than

74 diesel fuel. Scientists are interested in clarifying the characteristic emissions from the use of

75 BDFs, therefore, studies have been conducted on the use of B100 (100 \% BDFs), various blend

76 ratios, different types of engines and operating modes (Basha et al., 2009; Fontaras et al., 2009;

77 Lopes et al., 2014; Schröder et al., 2013a).

78 BFEG has been demonstrated to increase $\mathrm{NO}_{\mathrm{x}}$ and carbonyl compounds, which are important 79 ozone precursors. The highest emission of carbonyl compounds was found from B100(Chai et

80 al., 2013), and this result was consistent with those of other reports (Cardone et al., 2002;

81 Fontaras et al., 2009; He et al., 2009; Lin et al., 2009). These studies also indicated that

82 formaldehyde, acetaldehyde and acrolein were the most abundant carbonyl compounds under all

83 test conditions. The MIR method was applied to several models to estimate the ozone increase

84 associated with the use of BDFs (Chai et al., 2013; Gentner et al., 2013; Hadavi, 2013; Schröder,

85 1999). However, reports on the ozone increase determined experimentally using biodiesel

86 exhaust gas and a diesel fuel engine are not available. An achievement of this study was 
87 providing a better understanding of ozone as a secondary pollutant. We focused on the increase

88 in ozone when BDF was used as a substitute for conventional diesel fuel. Sunlight and test

89 chamber experiments were conducted and compared using ambient air and ambient air plus

90 exhaust gas. The impacts of $\mathrm{NO}_{\mathrm{x}}, \mathrm{NMHC}$, irradiation intensity and quality of the regional

91 ambient air between Hanoi, Vietnam and Osaka, Japan were evaluated.

\section{$92 \quad$ Experimental}

93 An electric power generator (Yanmar YDG $250 \mathrm{VS}$ with $2.5 \mathrm{kVA}$, four cylinders and direct

94 injection) was used for the emission test. $\mathrm{CO}, \mathrm{CO}_{2}$, hydrocarbon ( $\left.\mathrm{HC}\right)$, and $\mathrm{NO}_{\mathrm{x}}$ emissions from

95 biodiesel and diesel fuel were analyzed using a Horiba MEXA 584L. Commercial diesel fuel and

96 Jatroph $a$ and waste cooking oil (WCO) biodiesel fuels were used for testing. The Jatropha and

97 WCO biodiesel fuels and their qualities were reported in our previous study (Thanh et al., 2013).

98 Emission gases were collected in a $1-\mathrm{dm}^{3}$ glass vacuum bottle. Known volumes of exhaust were

99 then removed and injected into $18-\mathrm{dm}^{3}$ Teflon bags using a MS - CANX00 gastight syringe with

100 a volume of $30-\mathrm{cm}^{3}$. The Teflon bags were filled with $18-\mathrm{dm}^{3}$ of ambient air that was

101 homogenized before the experiment. The ambient air was collected in a $100-\mathrm{dm}^{3}$ Teflon bag

102 prior to homogenization, and the ambient air was then divided into three or four $18-\mathrm{dm}^{3}$ Teflon

103 bags. The flow rate was controlled using a mass flow controller (KOFLOC, Model 3660). The

104 18- $\mathrm{dm}^{3}$ Teflon bags were purchased from GL Sciences Co. Ltd. The transmittance of the Teflon

105 bags is shown in Figure 1 of the supporting information. The same volume of exhaust gas was

106 collected from the power generator while using biodiesel or diesel fuel during idle mode and

107 injected into two or three $18-\mathrm{dm}^{3}$ Teflon bags. One $18-\mathrm{dm}^{3}$ bag was filled with ambient air only.

108 The experiments were conducted under two irradiation conditions: one experiment was

109 conducted using natural sunlight on the roof of the B5 building, Nakamozu campus, Osaka 
110 Prefecture University, and the other experiment was conducted using four UV lamps in a test

111 chamber. In the first experiment, three Teflon bags were exposed to sunlight for 6 to 8 hours

112 after being filled with ambient air and with ambient air plus BFEG and DFEG. The

113 concentrations of ozone and $\mathrm{NO}_{\mathrm{x}}$ were analyzed after every two hours of irradiation. In the

114 second experiment, three Teflon bags (the same ones as above) were placed in the test chamber,

115 which had a cubic shape with dimensions of 110 (height) $\times 91$ x $91 \mathrm{~cm}$ for the measurements in

116 Osaka, Japan and dimensions of $105 \times 105 \times 105 \mathrm{~cm}$ for the measurements in Vietnam. The

117 interior walls of both test chambers were covered with aluminum tape for effective reflection.

118 Four IZ-SLH UV black lights lamp with wavelengths of $315 \sim 400 \mathrm{~nm}$ and powers of $21 \mathrm{~W}$

119 were used as the UV source. Ozone and $\mathrm{NO}_{\mathrm{x}}$ were detected using a Thermo Fisher Scientific

120 model 49 ozone analyzer and a $42 \mathrm{i} \mathrm{NO}_{\mathrm{x}}$ analyzer, respectively. The irradiation intensity and

121 meteorology factors in the test chamber were detected using a YK-35UV UV light meter

122 purchased from Lutron Electronic Enterprise Co., Ltd. Three bags were placed on a round

123 wooden plate with a diameter of $40.6 \mathrm{~cm}$ that could be rotated $360^{\circ}$. After varying the irradiation

124 time, the concentrations of $\mathrm{NO}_{\mathrm{x}}$ and $\mathrm{O}_{3}$ in the Teflon bag were analyzed. The solar intensity in

125 the summer (August and September) ranged from 2 to $4 \mathrm{~mW} \mathrm{~cm}{ }^{-2}$, whereas the UV light

126 intensity in the test chamber was only $0.2 \pm 0.02 \mathrm{~mW} \mathrm{~cm}^{-2}$. The photochemical reaction under

127 natural sunlight occurred very fast and reached its maximum within 2 hours; inside the test

128 chamber, the reaction required 24 - 30 hours and 12 hours for the Osaka and Hanoi experiments,

129 respectively.

130 To investigate and explain why the $\mathrm{NO}_{\mathrm{x}}$ concentration decreased in the air after the

131 photochemical reaction, two Teflon bags containing ambient air were used: One was placed in

132 the dark, and the other was exposed to UV light. To observe the decrease in $\mathrm{NO}_{\mathrm{x}}$ after irradiation, 
133 a known concentration of standard NO gas was spiked into both bags. After 36 hours, all air 134 samples were filtered using an ADVENTEC glass fiber filter, $90608702(47 \mathrm{~mm}$ i.d. and $0.6 \mu \mathrm{m}$ 135 pore size) before introduction into the $\mathrm{NO}_{\mathrm{x}}$ analyzer. The filter was extracted with $5 \mathrm{~cm}^{3}$ of 136 Millipore water (resistivity $\geq 18.2 \mathrm{M} \Omega \mathrm{cm}$ ) by shaking for $10 \mathrm{~min}$. The extracted solution was 137 then filtered using a $0.5-\mu \mathrm{m}$ filter, and the nitrate and nitrite concentrations were analyzed using 138 a Dionex ICS-1500 ion chromatograph (IC) (the eluent was a $9 \mathrm{mM} \mathrm{Na}_{2} \mathrm{CO}_{3}$ solution with a 1-

$139 \mathrm{~cm}^{3} /$ min flow rate). To wash the interior wall of the bag, $10 \mathrm{~cm}^{3}$ of pure water was added to the 140 bag before the air was added. The concentrations of $\mathrm{NO}_{2}{ }^{-}$and $\mathrm{NO}_{3}{ }^{-}$in the solution were analyzed 141 using IC and the same method mentioned above.

\section{$142 \quad$ Results and Discussion}

143 Primary emission of biodiesel and diesel fuels, ozone formation impacts

144 Biodiesel fuel is known to reduce $\mathrm{HC}$ emissions but increase $\mathrm{NO}_{\mathrm{x}}$ emissions. The primary 145 emissions from this study are shown in Figure 1 and are consistent with those of many previous 146 studies. Much of the literature reports that the use of pure BDFs increases $\mathrm{NO}_{\mathrm{x}}$ emissions (Basha 147 et al., 2009; Randazzo and Sodré, 2011; Xue et al., 2011). The use of BDFs reduces HC 148 emissions when compared to diesel; however, more carbonyl compounds are produced. These 149 compounds are the main cause of the photochemical reactions that form ozone in the troposphere. 150 Based on model calculations, William PL Carter proposed the MIR, which revealed that 151 carbonyl compounds have the greatest impact on ozone formation (Carter, 2010). Biodiesel fuel 152 emissions have high MIR and $\mathrm{NO}_{\mathrm{x}}$ concentrations, which is predictive of an increase in ozone.

\section{Ozone increase due to the use of biodiesel and diesel fuels}

154 VOCs and $\mathrm{NO}_{\mathrm{x}}$ are important well-known $\mathrm{O}_{3}$ precursors. Many studies have been conducted 155 on the important relationships between $\mathrm{NO}_{\mathrm{x}}$, VOCs and meteorological conditions as well as 
156 their roles in ozone formation (Atkinson, 2000; Itano et al., 2007; Li et al., 2013; Ling and Guo, 157 2014; Shao et al., 2009; Wang et al., 2008). VOCs include hundreds of organic compounds, and 158 the reactivity of each VOC is different. The contributions of individual VOCs with the highest 159 activities for ozone formation were calculated and reported, and it was found that NMHCs have 160 the highest activities (Borbon et al., 2002; Carter et al., 1995; Chai et al., 2013; Westphal et al., 161 2013; Xiao and Zhu, 2003). Ozone isopleth plots based on the simulation of the photochemical 162 reactions between $\mathrm{NO}_{x}, \mathrm{NMHCs}$ and VOCs were reported by (Jenkin and Clemitshaw, 2000; 163 Seinfeld. and Pandis., 2006; Sillman, 1999; Xiao and Zhu, 2003). These simulated results have 164 shown that the maximum $\mathrm{O}_{3}$ concentration depends on the initial concentrations of $\mathrm{NO}_{\mathrm{x}}$ and $165 \mathrm{NMHC}$, with a high $\mathrm{NMHC} / \mathrm{NO}_{\mathrm{x}}$ ratio corresponding to $\mathrm{NO}_{\mathrm{x}}$ sensitivity and a low $\mathrm{NMHC} / \mathrm{NO}_{\mathrm{x}}$ 166 ratio corresponding to NMHC sensitivity.

167 Our study tested both real sunlight and chamber conditions. In the sunlight experiments, the 168 irradiation of sunlight was performed over three months from August to October 2013. From 1 to $16910 \mathrm{~cm}^{3}$ of exhaust gas was added to 21 set samples (the set sample has consists of three bags: one 170 bag with ambient air, one bag with ambient air plus Jatropha BFEG and another with ambient 171 air plus DFEG), and each set sample was collected on different days. The original data are shown 172 in the supporting information (Figure 2). The data showed different results, indicating that the 173 ozone increase from the BFEG addition is higher than that from the DFEG on most days.

174 The results obtained under sunlight irradiation were evaluated using two methods: First, the 175 increase in the ozone concentration was calculated using the ratio between BFEG and DFEG 176 versus ambient air $\left(\Delta\left[\mathrm{O}_{3}\right]_{\text {Biodiesel }} / \Delta\left[\mathrm{O}_{3}\right]_{\text {Ambient air }}\right.$ and $\Delta\left[\mathrm{O}_{3}\right]_{\text {diesel }} / \Delta\left[\mathrm{O}_{3}\right]_{\text {ambient air }}$, where $\Delta\left[\mathrm{O}_{3}\right]$ is the 177 difference between the ozone concentration before and after irradiation. Figure 2 (a) presents the 178 correlation ratio. The larger number of points above the red line indicates an abundant and 
179 significant increase in ozone due to the use of biodiesel. Second, the increase in the ozone

180 concentration was calculated from the difference between BFEG and DFEG versus ambient air

$181\left(\left[\mathrm{O}_{3}\right]_{\text {Biodiesel }}-\left[\mathrm{O}_{3}\right]_{\text {Ambient air }}\right.$ and $\left.\left[\mathrm{O}_{3}\right]_{\text {Diesel }}-\left[\mathrm{O}_{3}\right]_{\text {Ambient air }}\right)$. The initial ozone concentration was

182 almost identical in all the three conditions because the dilution factor reached nearly 1000 , and

183 the initial state had no photochemical reactions. Figure 2 (b) shows this correlation and indicates

184 that the ozone increase resulting from BFEG was higher than that resulting from DFEG. The

185 results in Figure 2 were obtained from 83 measurements under the sunlight condition. The $t$-test

186 values were also examined to confirm the difference in the ozone increase between Jatropha-

187 BFEG and DFEG when compared with ambient air. The ratio and difference were 2.95 and 3.64 ,

188 respectively. In the evaluated methods, the ozone increase resulting from BFEG was higher than

189 that resulting from DFEG, with a confidence level greater than $99.9 \%$.

190 In the test chamber, $7.5,15$ and $30 \mathrm{~cm}^{3}$ of Jatropha-BFEG and DFEG were injected into 18-

$191 \mathrm{dm}^{3}$ air bags filled with ambient air. Figure 3 shows that differing amounts of exhaust gas result

192 in different $\mathrm{O}_{3}$ formation trends. In Figure 3 (a), which corresponds to the addition of $7.5 \mathrm{~cm}^{3}$ of

193 exhaust gas, the ozone from Jatropha-BFEG was always higher than the ozone from DFEG and

194 the ambient air. However, in Figures 3 (b) and (c), which correspond to the additions of $15 \mathrm{~cm}^{3}$

195 and $30 \mathrm{~cm}^{3}$ of exhaust gas, respectively, the ozone in DFEG was higher than the ozone in

196 Jatropha-BFEG after 12 hours of irradiation. More information is provided in Figures 3, 4, and 5

197 in the supporting information. This phenomenon will be explained in the next section, which

198 presents a comparison of the ozone formation trends in Japan and Vietnam. The maximum ozone

199 increases for each volume addition were also calculated and are shown in Figure 4. After 24 and

20036 hours of irradiation using UV light, the ozone in Jatropha-BFEG and DFEG significantly

201 increased when compared with ambient air without added exhausted gas. The black and blue 
202 lines show that the $\mathrm{O}_{3}$ value increased by adding DFEG and Jatropha-BFEG, respectively,

203 which increased from 7.2 to 17.4 ppb for DFEG and from 22.2 to 26.4 for Jatropha-BFEG. In

204 both sunlight and test chamber conditions, the ozone increase resulting from the use of BFEG

205 was always higher than that resulting from the use of DFEG. The result of this study is another

206 negative feature of biodiesel fuel in addition to the higher emissions of $\mathrm{NO}_{\mathrm{x}}$, carbonyl

207 compounds and LMW-ME, even though multiple benefits of BDFs have been recognized. To the

208 best of our knowledge, there were differences in the ozone increase between several of the

209 BFEGs and DFEGs, which were investigated and are shown in Table 1 (except for reference 16

210 gasoline/diesel). Our study used direct measurements of real samples, and the results were

211 consistent with the trend of the MIR method based on modeling (Hadavi, 2013; Schröder, 1999;

212 Schröder et al., 2013b).

213 Difference in ozone formation trends between Japan and Vietnam

214 Different ambient air qualities will create different ozone formation trends. In Osaka, the

215 annual mean concentrations of $\mathrm{NO}_{\mathrm{x}}$ and NMHCs in 2013 were $15.2 \mathrm{ppbv}$ and $198.3 \mathrm{ppbC}$,

216 respectively (these data were obtained from the Kanaoka continuous monitoring station, Osaka).

217 However, in Hanoi, the annual mean concentration of $\mathrm{NO}_{\mathrm{x}}$ in 2013 was $21.1 \mathrm{ppbv}$, and the

218 average concentration of NMHCs over five months in late 2013 was $445.7 \mathrm{ppbC}$ (these data were

219 obtained from the Vietnam Academy of Science and Technology continuous monitoring station,

220 Hanoi). Total hydrocarbon (THC) includes methane $\left(\mathrm{CH}_{4}\right)$ and $\mathrm{NMHCs}$. $\mathrm{CH}_{4}$ is an abundant

221 compound, but NMHCs are the main contributors to ozone formation (Itano et al., 2007; Xiao

222 and Zhu, 2003).

223 As shown in Figures 5 and 6, the ozone formation trends in Osaka and Hanoi were different.

224 NMHCs and $\mathrm{NO}_{x}$ are important ozone precursors, and the primary emission of the power 
generator contained $10.1 \pm 2.7 \mathrm{ppm} \mathrm{HC}$ and $84.7 \pm 8.0 \mathrm{NO}$ (means of eight samples \pm one

226 standard deviation). When $30 \mathrm{~cm}^{3}$ of exhaust gas was added to an $18-\mathrm{dm}^{3}$ Teflon bag filled with

227 ambient air from Osaka, Japan, and Hanoi, Vietnam, the spiked NMHC concentration was small

228 compared to the NMHC in ambient air, whereas the $\mathrm{NO}_{\mathrm{x}}$ concentration was significantly affected.

229 The maximum increases were 66 and $19 \mathrm{ppb}$ for Japan and Vietnam (see $\mathrm{NO}_{\mathrm{x}}$ graph in Figures 5

230 and 6), respectively. The addition of exhaust gas to the air bags in this experiment is similar to

231 the emissions from vehicles to the atmosphere. In our previous study, we observed the air quality

232 at Osaka Prefecture road number 29 at the cross-sector in Izumiotsu, Osaka, in December 2001

233 to investigate the contribution of $\mathrm{NO}_{\mathrm{x}}$ to ambient air from on-road vehicles and its transportation

234 by wind. The average wind speed in the daytime is $2.95 \mathrm{~m} \mathrm{~s}^{-1}$, and the wind direction is WNW

235 (west-north-west). To distinguish between upwind and downwind sources of $\mathrm{NO}_{\mathrm{x}}$, the $\mathrm{NO}_{\mathrm{x}}$

236 concentration was monitored. The average concentrations of $\mathrm{NO}_{\mathrm{x}}$ were 420.7 and $86.1 \mathrm{ppbv}$ for

237 upwind and downwind, respectively. Consequently, the upwind area was 4.9 times more

238 contaminated than the downwind area. This ratio would be further diluted by air mass

239 transportation. As with the above result, from 1 to $30 \mathrm{~cm}^{3}$ of biodiesel and diesel fuel exhaust gas

240 was spiked into $18-\mathrm{dm}^{3}$ of ambient air in this study. The dilution factors corresponded to 1,800

241 and 600 times, and the dilution ratio in our experiment was not far from the actual atmospheric

242 environments around the selected areas.

243 In Japan, the initial NMHCs concentration was approximately 200 ppbv in ambient air, and the

244 initial $\mathrm{NO}_{\mathrm{x}}$ concentration after adding $30 \mathrm{~cm}^{3}$ of exhaust gas ranged from 115 to $125 \mathrm{ppbv}$. The

245 ozone isopleth plot (Jenkin and Clemitshaw, 2000; Seinfeld. and Pandis., 2006; Sillman, 1999;

246 Xiao and Zhu, 2003) can explain why the ozone concentration of BFEG was lower than that of

247 DFEG after twelve hours of irradiation. However, after twelve hours, when the initial $\mathrm{NO}_{\mathrm{x}}$ 
concentration is less than 80 ppbv, the ozone concentration would primarily be affected by $\mathrm{NO}_{\mathrm{x}}$,

249 which means that the final ozone formation resulting from BFEG would be higher than that of

250 DFEG and ambient air. Therefore, $\mathrm{NO}_{\mathrm{x}}$ was the dominant factor controlling the photochemical

251 ozone under the condition of a high $\mathrm{NMHC} / \mathrm{NO}_{\mathrm{x}}$ ratio. Figure 6 shows the trend of the ozone

252 increase in Vietnam. The photochemical reaction in Vietnam was faster than that in Japan, and

253 the ozone increase resulting from BFEG was always the highest because the concentration of

254 NMHCs in Hanoi is approximately 450 ppbv. In this case, the $\mathrm{NO}_{\mathrm{x}}$ concentration is higher, and

255 more ozone will be produced. This result was also consistent with the ozone isopleth plot, which

256 was reported in previous studies, as mentioned above. The ozone increase depends on the type of

257 fuel, two types of biodiesel fuels (Jatropha and waste cooking oil) were used in Vietnam, and the

258 ozone increase resulting from the use of Jatropha-BFEG was slightly higher than that resulting

259 from the use of waste cooking oil-BFEG. With the same UV intensity, amount of added exhaust

260 gas and irradiation time, however, the largest ozone increases due to the use of biodiesel instead

261 of diesel in Japan and Vietnam were 31.2 and $42.8 \%$, respectively. This result indicates that if

262 the $\mathrm{NMHC} / \mathrm{NO}_{\mathrm{x}}$ ratio in ambient air is high, the addition of exhaust gas would significantly

263 affect the ozone increase.

264 Decrease in the $\mathrm{NO}_{\mathrm{x}}$ concentration during the photochemical reaction

265 The concentration of $\mathrm{NO}_{\mathrm{x}}$ was a sensitive factor in ozone formation, which involves a NO-to-

$266 \mathrm{NO}_{2}$ conversion reaction to form $\mathrm{O}_{3}$ in the presence of $\mathrm{NMHC}, \mathrm{M}$ (the third body) and light with

267 a wavelength shorter than $420 \mathrm{~nm}$, according to the following reactions:

$268 \quad \mathrm{NO}_{2}+\mathrm{O}_{2} \stackrel{h v, \mathrm{M}}{\longrightarrow} \mathrm{NO}+\mathrm{O}_{3}$

$269 \mathrm{NO}+\mathrm{ROO}^{\bullet} \rightarrow \mathrm{NO}_{2}+\mathrm{RO}^{\bullet}$

$270 \mathrm{NO}+\mathrm{O}_{3} \rightarrow \mathrm{NO}_{2}+\mathrm{O}_{2}$ 
271 However, the concentration of $\mathrm{NO}_{\mathrm{x}}$ decreased during both experiments under sunlight and

272 chamber conditions. For example, with Jatropha BFEG, the average $\mathrm{NO}_{\mathrm{x}}$ concentration

273 decreases were 44.1 and $72.3 \%$ after 8 hours under sunlight in Osaka and after 48 hours of

274 irradiation in the chamber, respectively. Figure 7 illustrates the decrease in the $\mathrm{NO}_{\mathrm{x}}$

275 concentration and products with and without irradiation, as well as in ambient air and ambient air

276 with added standard $\mathrm{NO}$ gas. Due to the low $\mathrm{NO}_{\mathrm{x}}$ concentration in the ambient air, it is difficult

277 to observe the decrease in the concentration of $\mathrm{NO}_{\mathrm{x}}$ in the air bag. Therefore, $\mathrm{NO}$ standard gas

278 was added to increase the initial $\mathrm{NO}_{\mathrm{x}}$ concentration for better observation. Most of the $\mathrm{NO}_{\mathrm{x}}$

279 became $\mathrm{HNO}_{3}$ in the ambient air and deposited on the interior of the bag after thirty-six hours of

280 radiation. However, in the ambient air plus $\mathrm{NO}$ with added sample, $\mathrm{NO}_{\mathrm{x}}$ remained; the $\mathrm{NO}_{3}{ }^{-}$

281 concentration was also not equal to the initial $\mathrm{NO}_{\mathrm{x}}$ concentration. $\mathrm{NO}_{3}{ }^{-}$in the particulate phase

282 was lower than the limit of detection in both the ambient air and spiked samples. Therefore, it is

283 concluded that $\mathrm{NO}_{3}{ }^{-}$was not absorbed by the particulate phase. In contrast, the concentration of

$284 \mathrm{NO}_{\mathrm{x}}$ did not decrease for thirty-six hours without irradiation, indicating that $\mathrm{NO}_{3}{ }^{-}$was not

285 formed if the photochemical reaction did not occur. The ratios of formed $\mathrm{NO}_{3}{ }^{-} /$initial $\mathrm{NO}_{\mathrm{x}}$ in the

286 ambient air and ambient air plus NO standard were 69.8 and $15.7 \%$, respectively. OH radicals

287 were formed in the photochemical cycle, followed by reaction with $\mathrm{NO}_{2}$ to become $\mathrm{HNO}_{3}$

288 (Atkinson, 2000). This reaction causes some loss of $\mathrm{NO}_{\mathrm{x}}$ during the daytime. For example, the

289 Jatropha-BFEG line from the Osaka chamber experiment shows that, at higher $\mathrm{O}_{3}$ and $\mathrm{OH}$ radical

290 concentrations, the $\mathrm{NO}_{\mathrm{x}}$ concentration is lower than in the DFEG and ambient air (Figure 5).

291 We hypothesized that $\mathrm{NO}_{\mathrm{x}}$ react with $\mathrm{OH}$ radicals and VOCs to form unknown organic nitrates

292 in addition to $\mathrm{HNO}_{3}$. The yields of the unknown organic compounds depend on the initial $\mathrm{NO}_{\mathrm{x}}$ 
293 concentrations. The formation of the unknown organic nitrate due to the use of biodiesel and

294 diesel fuels will be investigated in future work.

\section{Conclusion}

296 The results of this study are confirmed that the ozone was increased by the use of biodiesel

297 and diesel fuel. The direct measurement method was applied to evaluate the different trend of

298 ozone formation: The ozone increment from BFEG is abundant and significant compared to

299 DFEG under all experimental conditions, and the ozone concentration was increased with

300 increasing amount of exhausted gas addition, which is available for considering BDFs as an

301 alternative fuel. Due to different ambient air composition, the trend of ozone increment between

302 Vietnam and Japan are different: 1) ozone increment in Vietnam was higher and faster than Japan.

303 2) The ozone increment resulting from the use of BFEG in Vietnam was high compared to that

304 from DFEG under all experimental conditions, but in Japan the opposite results were observed.

305 The ozone increment by Jatropha-BFEG was slightly higher than that by waste cooking oil-BFEG.

306 The ozone increment depends on radiation intensity, quality of ambient air and NMHCs/NOx ratio.

307 Author information

308 Corresponding author

$309 *$ E-mail: thang236@gmail.com

\section{Acknowledgments}

311 This research was partially supported by the Japan Science and Technology Agency and Japan 312 International Cooperation Agency, Science and Technology Research Partnership for Sustainable 313 Development (SATREPS project entitled "Multi-beneficial measure for mitigation of climate 314 change in Vietnam and Indochina countries by development of biomass energy"). 
The data are published online at http://taiki.kankyo.pref.osaka.jp/taikiWebApp/bin/form1000/Form_1190.jsp (in japanese)

Atkinson, R., 2000. Atmospheric chemistry of VOCs and NOx. Atmos. Environ. 34, 2063-2101.

Basha, S.A., Gopal, K.R., Jebaraj, S., 2009. A review on biodiesel production, combustion, emissions and performance. Renew. Sust. Energ. Rev. 13, 1628-1634.

Basha, S.A., Raja G., K., 2012. A review of the effects of catalyst and additive on biodiesel production, performance, combustion and emission characteristics. Renew. Sust. Energ. Rev. 16, 711-717.

Borbon, A., Locoge, N., Veillerot, M., Galloo, J.C., Guillermo, R., 2002. Characterisation of NMHCs in a French urban atmosphere: overview of the main sources. Sci.Total Environ. 292, 177-191.

Cardone, M., Prati, M.V., Rocco, V., Seggiani, M., Senatore, A., Vitolo, S., 2002. Brassica carinata as an Alternative Oil Crop for the Production of Biodiesel in Italy: Engine Performance and Regulated and Unregulated Exhaust Emissions. Environ. Sci. Technol. 36, 4656-4662.

Carter, W.P.L., 1994. Development of Ozone Reactivity Scales for Volatile Organic Compounds. J. Air Waste Manage. Assoc. 44, 881-899.

Carter, W.P.L., 2010. Updated Maximum Incremental Reactivity Scale and Hydrocarbon Bin Reactivities for Regulatory Applications. Report for California Air Resources Board Contract 07-339. Available at: http://www.engr.ucr.edu/ carter/SAPRC/MIR10.pdf (accessed April 27, 2016).

Carter, W.P.L., Atkinson, R., 1987. An experimental study of incremental hydrocarbon reactivity. Environ. Sci. Technol. 21, 670-679.

Carter, W.P.L., Atkinson, R., 1989. Computer modeling study of incremental hydrocarbon reactivity. Environ. Sci. Technol. 23, 864-880.

Carter, W.P.L., Pierce, J.A., Luo, D., Malkina, I.L., 1995. Environmental chamber study of maximum incremental reactivities of volatile organic compounds. Atmos. Environ. 29, 2499-2511.

Chai, M., Lu, M., Liang, F., Tzillah, A., Dendramis, N., Watson, L., 2013. The use of biodiesel blends on a non-road generator and its impacts on ozone formation potentials based on carbonyl emissions. Environ. Pollut. 178, 159-165.

Dong, D., Shao, M., Li, Y., Lu, S., Wang, Y., Ji, Z., Tang, D., 2014. Carbonyl emissions from heavy-duty diesel vehicle exhaust in China and the contribution to ozone formation potential. J. Environ. Sci. 26, 122-128. 
Dorado, M.P., Ballesteros, E., Arnal, J.M., Gómez, J., López, F.J., 2003. Exhaust emissions from a Diesel engine fueled with transesterified waste olive oil. Fuel 82, 1311-1315.

Fernando, S., Hall, C., Jha, S., 2005. NOx Reduction from Biodiesel Fuels. Energ. Fuel 20, 376382.

Fontaras, G., Karavalakis, G., Kousoulidou, M., Tzamkiozis, T., Ntziachristos, L., Bakeas, E., Stournas, S., Samaras, Z., 2009. Effects of biodiesel on passenger car fuel consumption, regulated and non-regulated pollutant emissions over legislated and real-world driving cycles. Fuel 88, 1608-1617.

Gentner, D.R., Worton, D.R., Isaacman, G., Davis, L.C., Dallmann, T.R., Wood, E.C., Herndon, S.C., Goldstein, A.H., Harley, R.A., 2013. Chemical Composition of Gas-Phase Organic Carbon Emissions from Motor Vehicles and Implications for Ozone Production. Environ. Sci. Technol. 47, 11837-11848.

Guarieiro, L.L.N., de Souza, A.F., Torres, E.A., de Andrade, J.B., 2009. Emission profile of 18 carbonyl compounds, $\mathrm{CO}, \mathrm{CO}_{2}$, and $\mathrm{NO}_{\mathrm{x}}$ emitted by a diesel engine fuelled with diesel and ternary blends containing diesel, ethanol and biodiesel or vegetable oils. Atmos. Environ. 43, 2754-2761.

Hadavi, S., Andrews, G.E., Li, H., Przybyla, G., Vazirian, M., 2013. Diesel Cold Start into Congested Real World Traffic Comparison of Diesel and B100 for Ozone Forming Potential. SAE international.

He, C., Ge, Y., Tan, J., You, K., Han, X., Wang, J., You, Q., Shah, A.N., 2009. Comparison of carbonyl compounds emissions from diesel engine fueled with biodiesel and diesel. Atmos. Environ. 43, 3657-3661.

Itano, Y., Bandow, H., Takenaka, N., Saitoh, Y., Asayama, A., Fukuyama, J., 2007. Impact of NOx reduction on long-term ozone trends in an urban atmosphere. Sci. Total Environ. 379, 46-55.

Jenkin, M.E., Clemitshaw, K.C., 2000. Ozone and other secondary photochemical pollutants: chemical processes governing their formation in the planetary boundary layer. Atmos. Environ. 34, 2499-2527.

Li, H., Altaher, M.A., Andrews, G.E., 2011. Aldehydes Emissions Measurement and OFP assessment of Biodiesel and its Blends with Kerosene using a Low NOx Gas Turbine Combustor. Proceedings of the ASME Turbo Expo GT2011-45707, 671-680.

Li, Y., Lau, A.K.H., Fung, J.C.H., Zheng, J., Liu, S., 2013. Importance of NOx control for peak ozone reduction in the Pearl River Delta region. J. Geophys. Res. Atmos. 118, 9428-9443.

Lin, Y.-C., Lee, W.-J., Wu, T.-S., Wang, C.-T., 2006. Comparison of PAH and regulated harmful matter emissions from biodiesel blends and paraffinic fuel blends on engine accumulated mileage test. Fuel 85, 2516-2523. 
Lin, Y.-C., Wu, T.-Y., Ou-Yang, W.-C., Chen, C.-B., 2009. Reducing emissions of carbonyl compounds and regulated harmful matters from a heavy-duty diesel engine fueled with paraffinic/biodiesel blends at one low load steady-state condition. Atmos. Environ. 43, 2642-2647.

Ling, Z.H., Guo, H., 2014. Contribution of VOC sources to photochemical ozone formation and its control policy implication in Hong Kong. Environ. Sci. Policy 38, 180-191.

Lopes, M., Serrano, L., Ribeiro, I., Cascão, P., Pires, N., Rafael, S., Tarelho, L., Monteiro, A., Nunes, T., Evtyugina, M., Nielsen, O.J., Gameiro da Silva, M., Miranda, A.I., Borrego, C., 2014. Emissions characterization from EURO 5 diesel/biodiesel passenger car operating under the new European driving cycle. Atmos. Environ. 84, 339-348.

Mellouki, A., Wallington, T.J., Chen, J., 2015. Atmospheric Chemistry of Oxygenated Volatile Organic Compounds: Impacts on Air Quality and Climate. Chem. Rev. 115, 3984-4014.

Orlando, J.P., Alvim, D.S., Yamazaki, A., Corrêa, S.M., Gatti, L.V., 2010. Ozone precursors for the São Paulo Metropolitan Area. Sci. Total Environ. 408, 1612-1620.

Randazzo, M.L., Sodré, J.R., 2011. Exhaust emissions from a diesel powered vehicle fuelled by soybean biodiesel blends (B3-B20) with ethanol as an additive (B20E2-B20E5). Fuel 90, 98-103.

Ribeiro, I., Monteiro, A., Lopes, M., 2016. Potential effects of using biodiesel in road-traffic on air quality over the Porto urban area, Portugal. Atmos. Environ. 125, Part A, 78-91.

Schröder, O., Bünger, J., Munack, A., Knothe, G., Krahl, J., 2013a. Exhaust emissions and mutagenic effects of diesel fuel, biodiesel and biodiesel blends. Fuel 103, 414-420.

Schröder, O., Bünger, J., Munack, A., Knothe, G., Krahl, J., 2013b. Exhaust emissions and mutagenic effects of diesel fuel, biodiesel and biodiesel blends. Fuel 103, 414-420.

Schröder, O., Krahl, J , Munack, A, Bünger, J, 1999. Environmental and health effects caused by the use of biodiesel. International Fall Fuels and Lubricants Meeting and Exposition; Toronto, ON; Canada.

Seinfeld., J.H., Pandis., S.N., 2006. Atmospheric Chemistry and Physics. John Wiley \& Sons, Inc. Second edidtion.

Shao, M., Zhang, Y., Zeng, L., Tang, X., Zhang, J., Zhong, L., Wang, B., 2009. Ground-level ozone in the Pearl River Delta and the roles of VOC and NOx in its production. J. Environ. Manage. 90, 512-518.

Shin, H.-M., McKone, T.E., Bennett, D.H., 2016. Volatilization of low vapor pressure - volatile organic compounds (LVP-VOCs) during three cleaning products-associated activities: Potential contributions to ozone formation. Chemosphere 153, 130-137.

Sillman, S., 1999. The relation between ozone, NOx and hydrocarbons in urban and polluted rural environments. Atmos. Environ. 33, 1821-1845. 
424 Thang, P.Q., Maeda, Y., Trung, N.Q., Takenaka, N., 2014. Low molecular weight methyl ester 425 in diesel/waste cooking oil biodiesel blend exhausted gas. Fuel 117, Part B, 1170-1171. 426 Thang, P.Q., Maeda, Y., Trung, N.Q., Takenaka, N., 2016. Detailed chemical kinetics for 427 thermal decomposition of low molecular weight-methyl esters generated by using biodiesel fuel. Environ. Prog. Sustainable Energy., doi: 10.1002/ep.12309.

Thanh, L.T., Okitsu, K., Sadanaga, Y., Takenaka, N., Maeda, Y., Bandow, H., 2013. A new cosolvent method for the green production of biodiesel fuel - Optimization and practical application. Fuel 103, 742-748.

Wang, Q.g., Han, Z., Wang, T., Zhang, R., 2008. Impacts of biogenic emissions of VOC and NOx on tropospheric ozone during summertime in eastern China. Sci. Total Environ. 395, 41-49.

Westphal, G.A., Krahl, J., Munack, A., Rosenkranz, N., Schröder, O., Schaak, J., Pabst, C., Brüning, T., Bünger, J., 2013. Combustion of Hydrotreated Vegetable Oil and Jatropha Methyl Ester in a Heavy Duty Engine: Emissions and Bacterial Mutagenicity. Environ. Sci. Technol. 47, 6038-6046.

Xiao, H., Zhu, B., 2003. Modelling Study of Photochemical Ozone Creation Potential of NonMethane Hydrocarbon. Water Air Soil Pollut. 145, 3-16.

Xue, J., Grift, T.E., Hansen, A.C., 2011. Effect of biodiesel on engine performances and emissions. Renew. Sust. Energ. Rev. 15, 1098-1116.

Zhu, L., Cheung, C.S., Zhang, W.G., Huang, Z., 2010. Emissions characteristics of a diesel engine operating on biodiesel and biodiesel blended with ethanol and methanol. Sci. Total 
449 Table 1: Comparison of the ozone increase due to different fuels, engines and calculation 450 methods.

451

\begin{tabular}{|c|c|c|c|c|c|}
\hline No & Type of fuel & Type of engine & $\begin{array}{c}\text { Maximum ozone } \\
\text { increase }(\%)\end{array}$ & $\begin{array}{c}\text { Calculation } \\
\text { method }\end{array}$ & Reference \\
\hline 1 & $\begin{array}{l}\text { Vegetable BDF/ } \\
\text { diesel }\end{array}$ & Passenger car & 284 & MIR method & $\begin{array}{l}\text { (Hadavi, } \\
\text { 2013) }\end{array}$ \\
\hline 2 & $\begin{array}{l}\text { Soybean and waste } \\
\text { vegetable BDF/ } \\
\text { diesel }\end{array}$ & $\begin{array}{l}\text { Non-road } \\
\text { generator }\end{array}$ & 34.7 & MIR method & $\begin{array}{c}\text { (Chai et al., } \\
\text { 2013) }\end{array}$ \\
\hline 3 & $\begin{array}{l}\text { Rapeseed } \\
\text { BDF/diesel }\end{array}$ & $\begin{array}{l}\text { One cylinder and } \\
\text { four cylinder } \\
\text { Farymann }\end{array}$ & 30 & MIR method & $\begin{array}{c}\text { (Schröder, } \\
\text { 1999) }\end{array}$ \\
\hline 4 & Gasoline/diesel & Motor vehicles & 45.5 & MIR method & $\begin{array}{l}\text { (Gentner et } \\
\text { al., 2013) }\end{array}$ \\
\hline 5 & $\begin{array}{l}\text { Waste cooking oil } \\
\mathrm{BDF} / \text { Kerosene }\end{array}$ & $\begin{array}{l}\text { The premixed gas } \\
\text { turbine combustor } \\
\text { test rig }\end{array}$ & 50 & MIR method & $\begin{array}{l}\text { (Li et al., } \\
\text { 2011) }\end{array}$ \\
\hline 6 & $\begin{array}{l}\text { Jatropha-BDF and } \\
\text { WCO-BDF/diesel }\end{array}$ & Power generator & $31.2-42.8$ & $\begin{array}{l}\text { Direct } \\
\text { measurement }\end{array}$ & This study \\
\hline
\end{tabular}



467 added.

468 Figure 4. Maximum ozone increases due to the addition of different volumes of exhaust gas 469 with a UV lamp in the test chamber.

470 The columns are different ozone concentrations, and the lines are the maximum increases in 471 the ozone values.

472 Figure 5. The trends of the ozone increase and $\mathrm{NO}_{\mathrm{x}}$ decrease under UV irradiation in Japan 473 after adding $30-\mathrm{cm}^{3}$ of exhaust gas under the following test chamber conditions:

474 Blue: 18-dm ${ }^{3}$ ambient air; red: $18-\mathrm{dm}^{3}$ ambient air plus DFEG; green: $18-\mathrm{dm}^{3}$ ambient air plus 475

\section{Figure captions}

Figure 1. Primary emissions from the three types of fuels and a power engine generator: The $\mathrm{CO}, \mathrm{HC}$, and $\mathrm{NO}_{\mathrm{x}}$ concentrations are in ppm (vol), and the $\mathrm{CO}_{2}$ is in \% (vol). Brown column: DFEG; Blue column: Jatropha-BFEG; Green column: Waste cooking oil-BFEG. The columns present the average of eight samples, and the error bars show the standard deviations.

Figure 2. Correlation between the ozone increases due to Jatropha-BFEG and DFEG versus ambient air under sunlight.

Figure 2 (a) shows the ratio, and Figure 2 (b) shows the difference. The red line indicates a 1:1 ratio; please refer to the text for more detail.

Figure 3. Different volumes of exhaust gas were added to Teflon bags with ambient air from Osaka, Japan under a UV lamp in the following test chamber conditions:

Blue: $18 \mathrm{dm}^{3}$ ambient air; red: $18 \mathrm{dm}^{3}$ ambient air plus DFEG; green: $18-\mathrm{dm}^{3}$ ambient air plus Jatropha-BFEG. Figure 3-(a) $7.5 \mathrm{~cm}^{3}$ added, Figure 3-(b) $15 \mathrm{~cm}^{3}$ added and Figure 3- (c) $30 \mathrm{~cm}^{3}$

\section{Jatropha-BFEG.}


476 Figure 6. The trends of the ozone increase and $\mathrm{NO}_{\mathrm{x}}$ decrease in Vietnam after the addition of $477 \quad 30 \mathrm{~cm}^{3}$ of exhaust gas.

478 Blue: $18-\mathrm{dm}^{3}$ ambient air; red: $18-\mathrm{dm}^{3}$ ambient air plus diesel exhausted gas; green: $18-\mathrm{dm}^{3}$

479 ambient air plus Jatropha-BFEG; Black: 18- $\mathrm{dm}^{3}$ ambient plus WCO-BFEG.

480 Figure 7. Decrease in the $\mathrm{NO}_{\mathrm{x}}$ concentration in ambient air and ambient air spiked with the

$481 \quad$ NO standard due to the photochemical processes.

482 Columns are the averages of six samples, and the error bars show the standard deviation.

483 

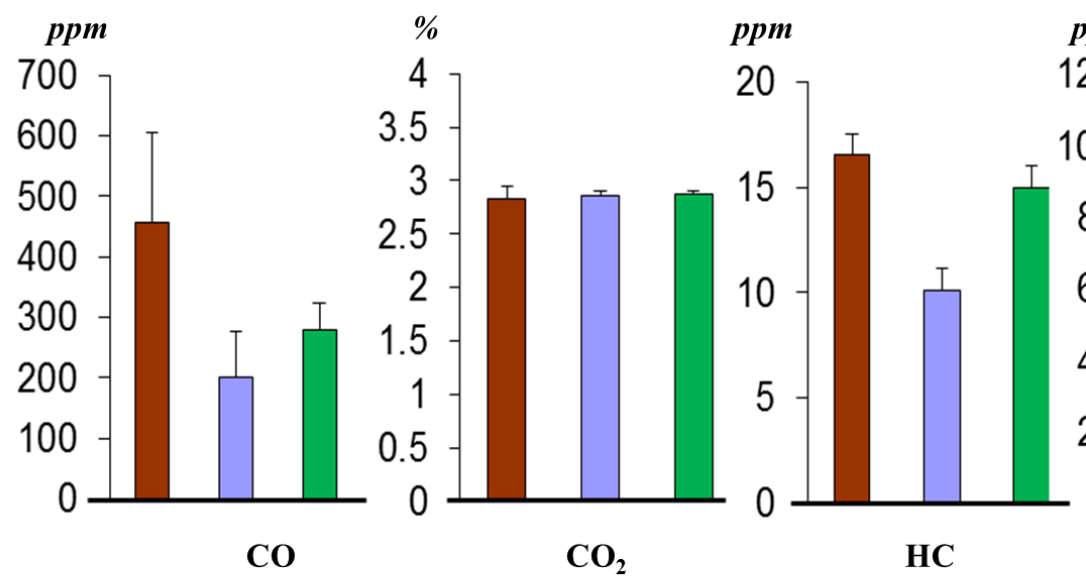

ppm

491

DFE

Jatropha - BDFE

HC

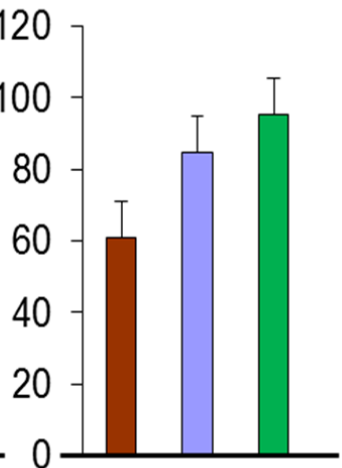

NOx

WCO - BDFE

492

493

494

Figure 1 Thang P.Q. et al.

495 


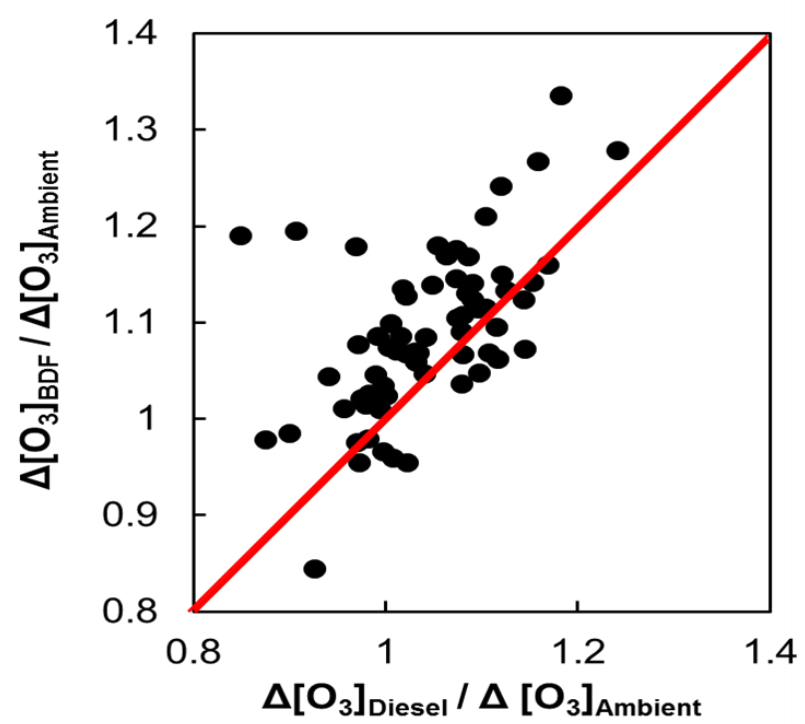

(a)

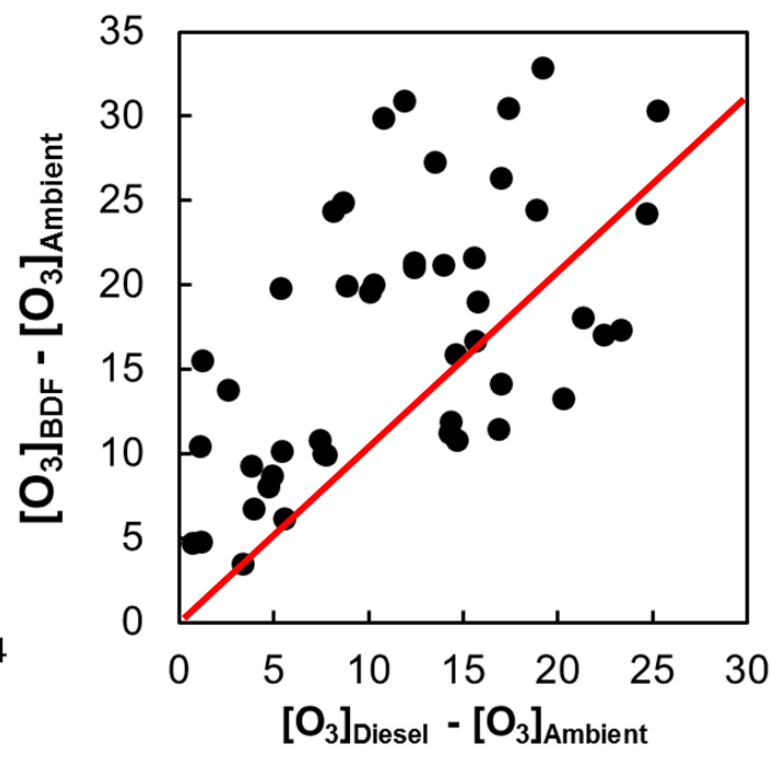

(b)

508

Figure 2 Thang P.Q. et al.

510

511 

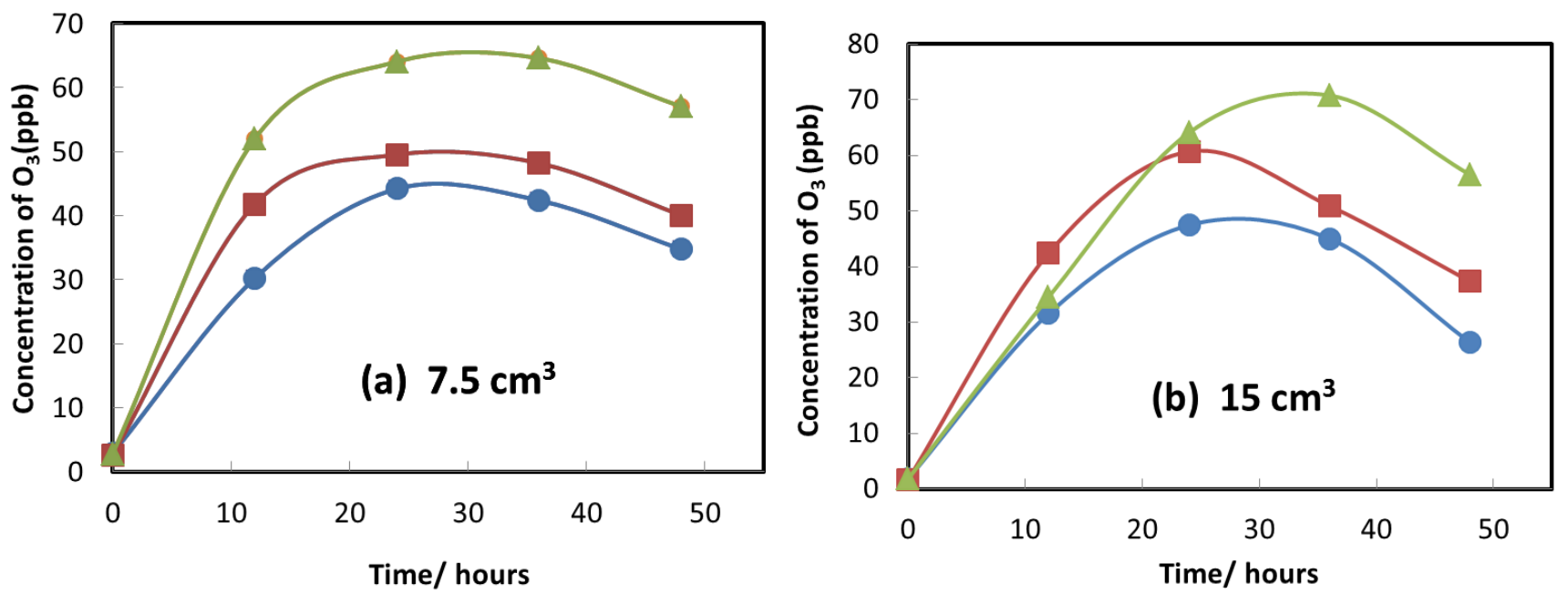

513

514

515

516

517

518

519

520

521

522

523

524

525

526

527

528

529

530

531

532

533

534

535

536

537

538

539

540

541

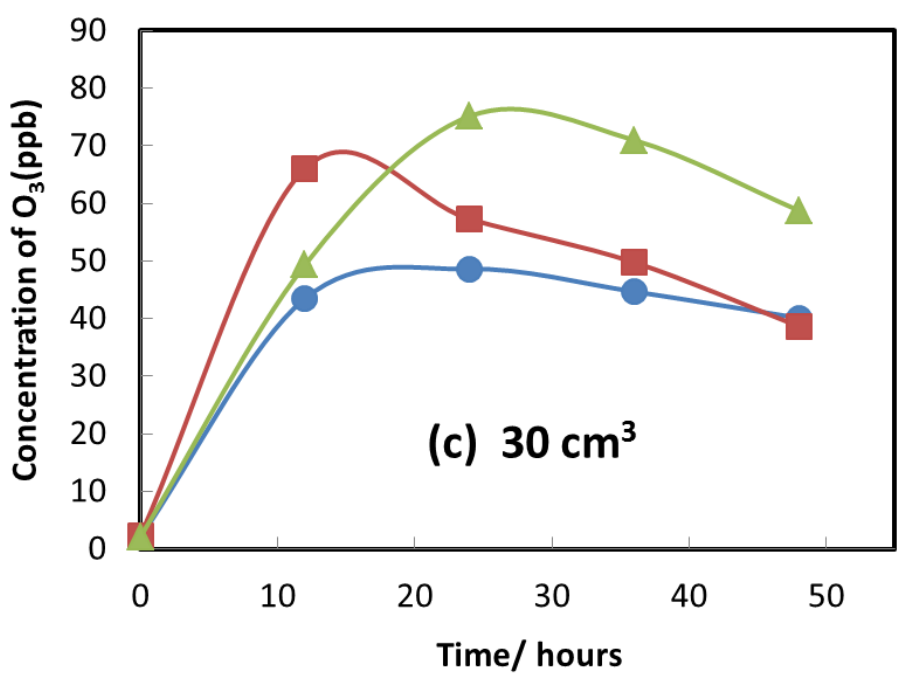

Ambient air

Ambient air + Diesel

$\Delta$ Ambient air + Biodiesl

542

Figure 3 Thang P.Q. et al. 


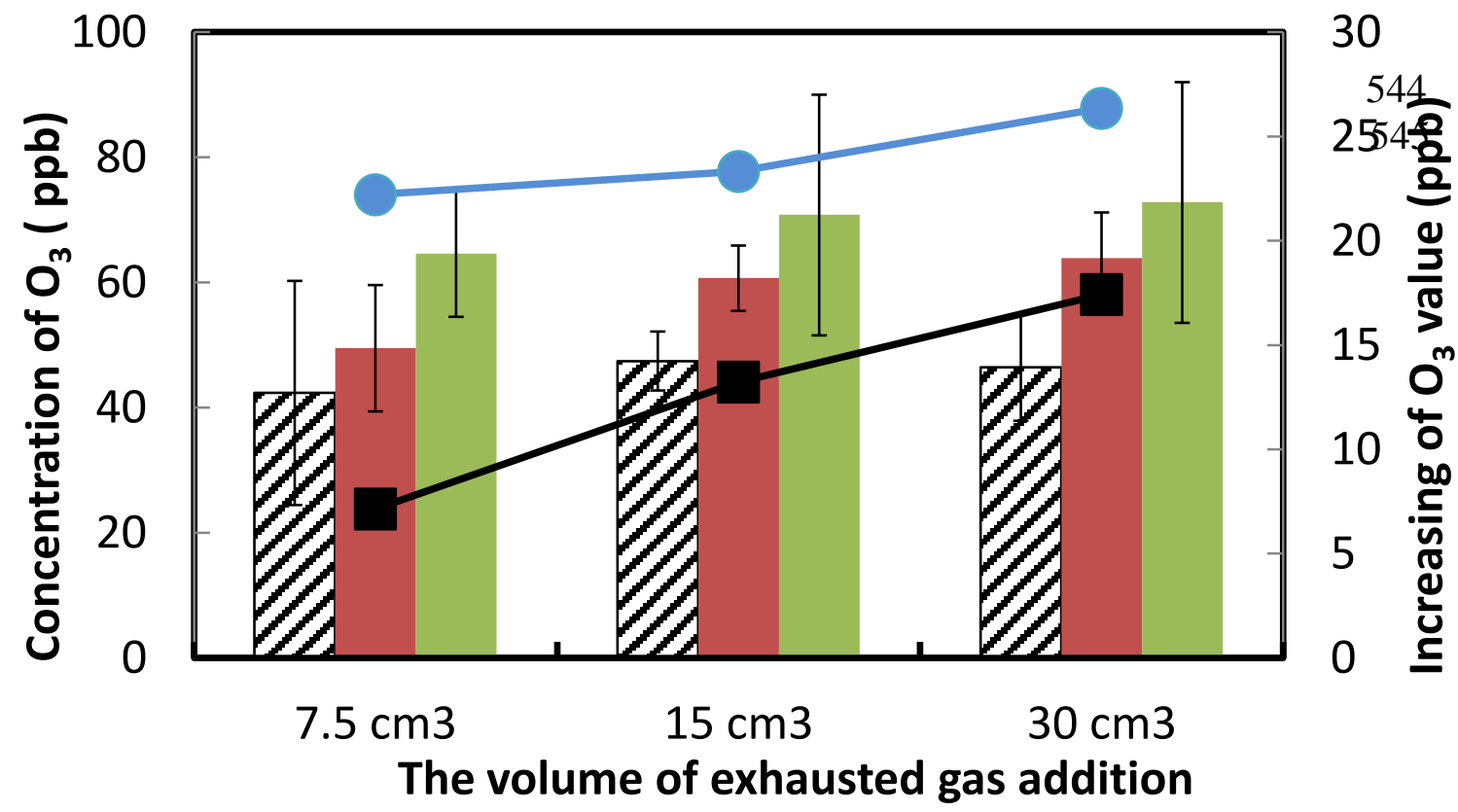

556

557

558

559

560

561

562

563

564

565

एखिAmbient air

Ambient air + Diesel

Ambient air + Jatropha-BDF

-Increasing of $\mathrm{O}_{3}$ value by adding diesel's exhausted gas

566

567

568

569

570

571

572

573

574

575

576

577

578

Figure 4 Thang P.Q. et al.

579

580 


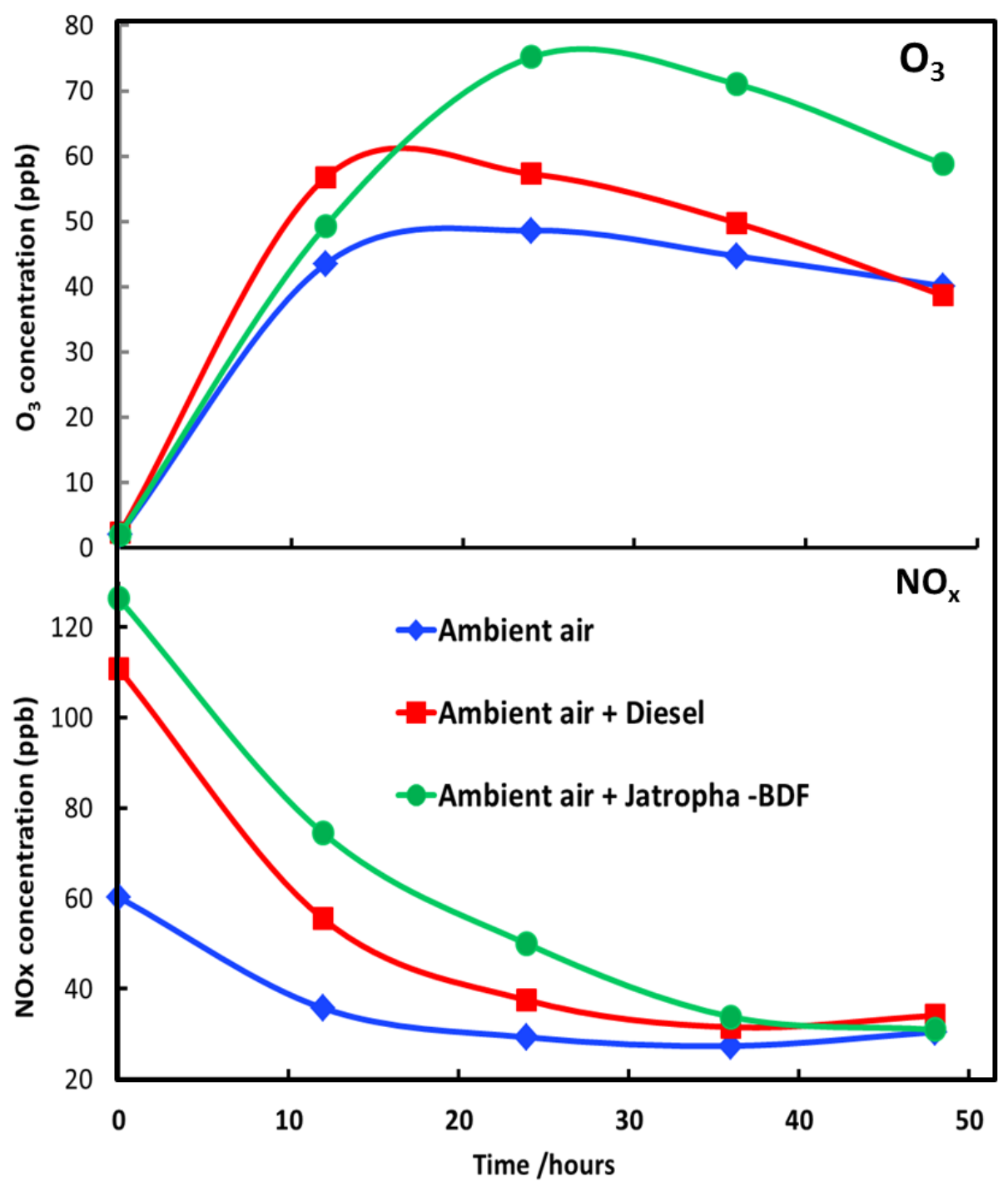

602

603

604

Figure 5 Thang P.Q. et al.

605 
608

609

610

611

612

613

614

615

616

617

618

619

620

621

622

623

624

625

626

627

628

629

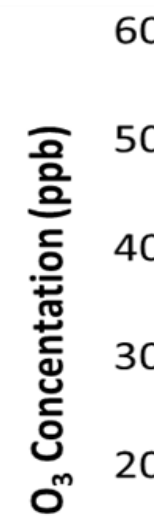

60
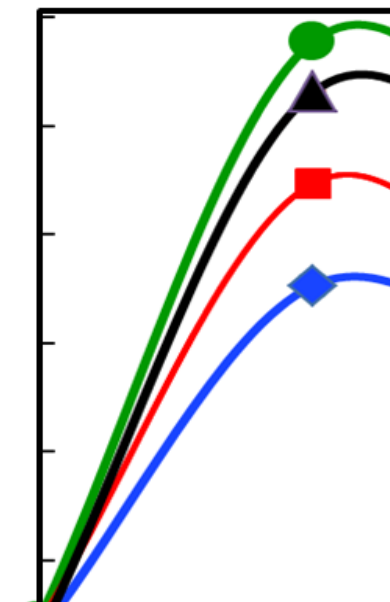

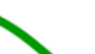

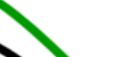

$0_{3}$

3

10

0

2

1

7

응 60

0

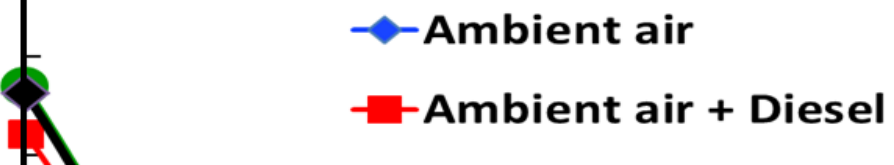

0

-Ambient air + Jatropha -BDF

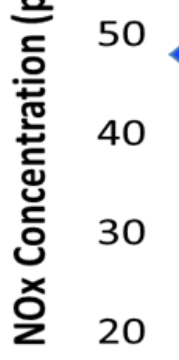

-Ambient air + WCO -BDF

630

631

Figure 6 Thang P.Q. et al.

632

633

634

635 


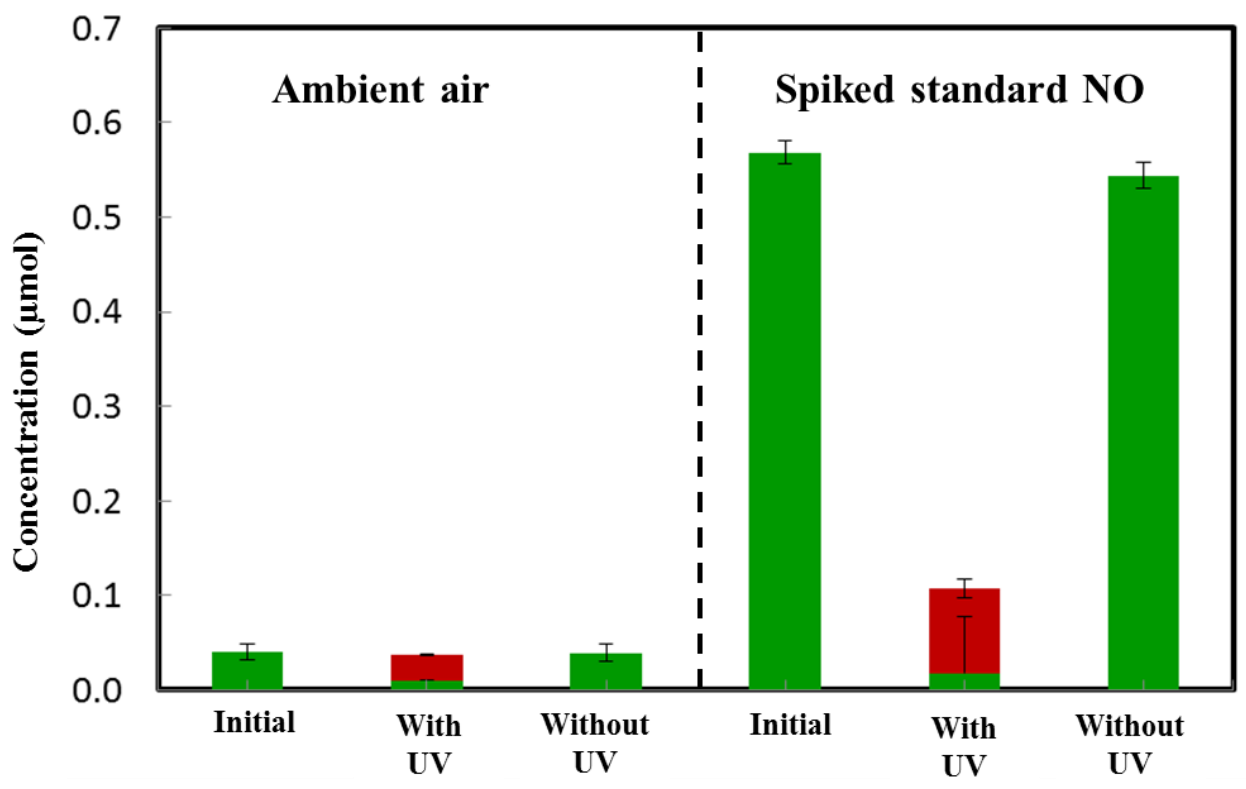




\section{Graphical abstract}

662

663

664

665

666

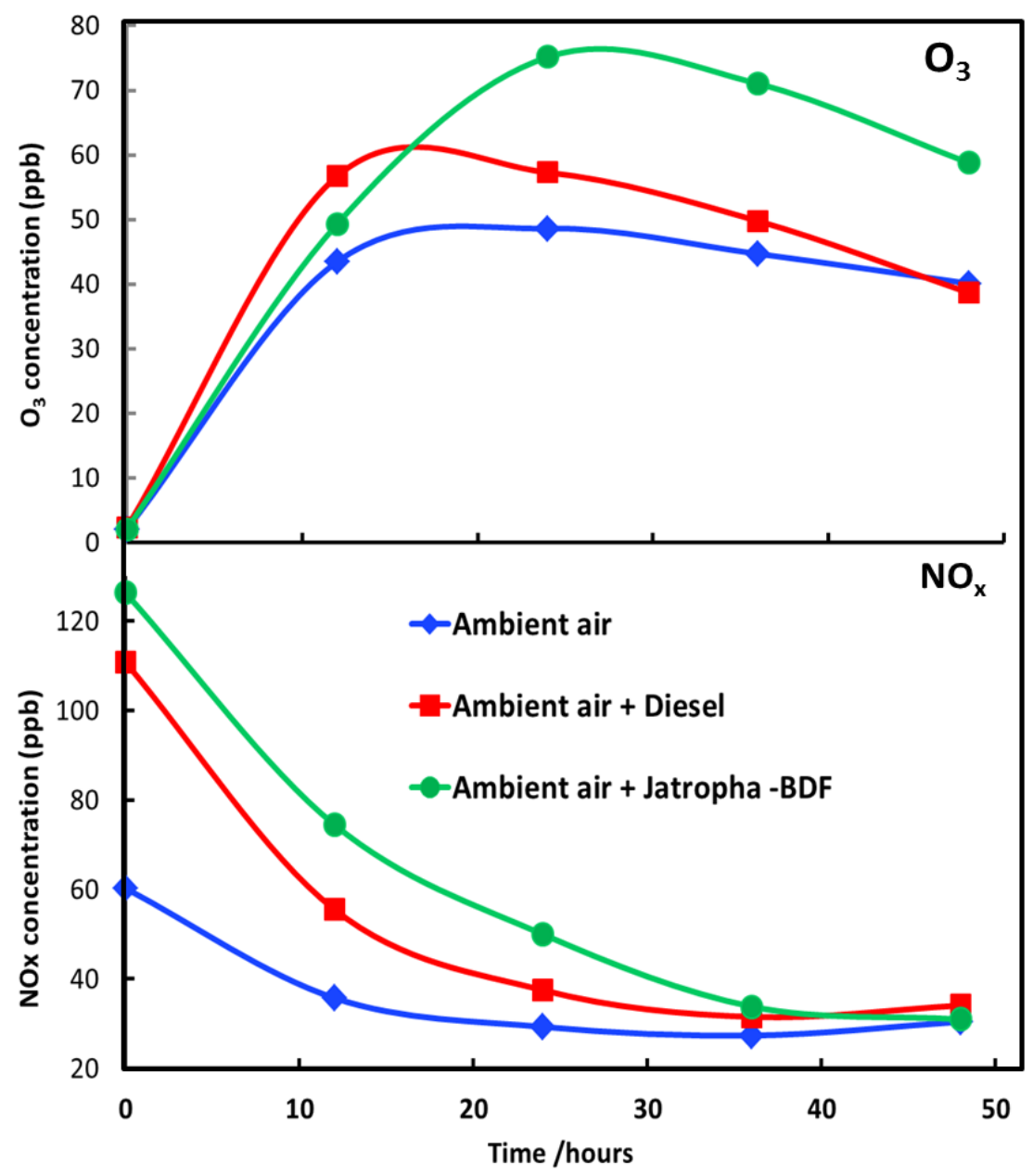

